\title{
Inhibitory Role of Growth Hormone in the Induction and Progression Phases of Collagen-Induced Arthritis
}

\author{
Ricardo Villares' ${ }^{1}$ Gabriel Criado², Yasmina Juarranz ${ }^{3}$, Mercedes Lopez-Santalla ${ }^{4,5}$, \\ Eva M. García-Cuesta ${ }^{1}$, José M. Rodríguez-Frade ${ }^{1}$, Javier Leceta ${ }^{3}$, Pilar Lucas ${ }^{1}$, \\ José Luis Pablos ${ }^{2}$, Carlos Martínez-A', Marina I. Garin ${ }^{4,5}$, Rosa P. Gomariz ${ }^{3}$ \\ and Mario Mellado ${ }^{\text {* }}$
}

\begin{abstract}
${ }^{1}$ Department of Immunology and Oncology, Centro Nacional de Biotecnología/CSIC, Madrid, Spain, ${ }^{2}$ Inflammatory and Autoimmune Diseases Group, Instituto de Investigación Hospital 12 de Octubre (i+12), Madrid, Spain, ${ }^{3}$ Departamento de Biología Celular, Facultad de Biología, Universidad Complutense de Madrid, Madrid, Spain, ${ }^{4}$ Division of Hematopoietic Innovative Therapies, Centro de Investigaciones Energéticas Medioambientales y Tecnológicas (CIEMAT) and Centro de Investigación Biomédica en Red de Enfermedades Raras (CIBERER-ISCIII), Madrid, Spain, ${ }^{5}$ Advanced Therapy Unit, Instituto de Investigación Sanitaria Fundación Jiménez Díaz (IIS-FJD/UAM), Madrid, Spain
\end{abstract}

OPEN ACCESS

Edited by:

Teizo Yoshimura

Okayama University, Japan

Reviewed by:

Toshihiro Ito,

Nara Medical University, Japan

Toshikazu Kondo,

Wakayama Medical University,

Japan

${ }^{*}$ Correspondence:

Mario Mellado

mmellado@cnb.csic.es

Specialty section:

This article was submitted to Cytokines and Soluble Mediators in Immunity,

a section of the journal

Frontiers in Immunology

Received: 20 November 2017 Accepted: 09 May 2018 Published: 25 May 2018

Citation:

Villares $R$, Criado G, Juarranz Y, Lopez-Santalla M, GarcíaCuesta EM, Rodríguez-Frade JM,

Leceta J, Lucas P, Pablos JL, Martínez-A C, Garin MI, Gomariz RP and Mellado M (2018) Inhibitory Role of Growth Hormone in the Induction and Progression Phases of Collagen-Induced Arthritis.

Front. Immunol. 9:1165. doi: 10.3389/fimmu.2018.01165
Evidence indicates an intimate connection between the neuroendocrine and the immune systems. A number of in vitro and in vivo studies have demonstrated growth hormone $(\mathrm{GH})$ involvement in immune regulation. The $\mathrm{GH}$ receptor is expressed by several leukocyte subpopulations, and GH modulates immune cell proliferation and activity. Here, we found that sustained $\mathrm{GH}$ expression protected against collagen-induced arthritis (CIA); in GH-transgenic C57BL/6 (GHTg) mice, disease onset was delayed, and its overall severity was decreased. The anti-collagen response was impaired in these mice, as were inflammatory cytokine levels. Compared to control arthritic littermates, immunized GHTg mice showed significantly lower RORyt (retinoic acid receptor-related orphan receptor gamma 2), IL-17, GM-CSF, IL-22, and IFNy mRNA expression in draining lymph nodes, whereas there were no differences in IL-21, IL-6, or IL-2 mRNA levels. Data thus suggest that Th17/Th1 cell plasticity toward a pathological phenotype is reduced in these mice. Exogenous $\mathrm{GH}$ administration in arthritic DBA $1 \mathrm{~J}$ mice reduced the severity of established CIA as well as the inflammatory environment, which also shows a GH effect on arthritis progression. These results indicate that GH prevents inflammatory joint destruction in CIA. Our findings demonstrate a modulatory $\mathrm{GH}$ role in immune system function that contributes to alleviating CIA symptoms and underlines the importance of endocrine regulation of the immune response.

Keywords: collagen-induced arthritis, growth hormone, Th17/Th1 cells, cytokines, immune regulation

\section{INTRODUCTION}

Growth hormone $(\mathrm{GH})$ is secreted by the anterior pituitary in vertebrates. Although initially defined as a major stimulant in somatic growth control, it is in fact a pleiotropic hormone that affects many physiological functions. GH regulates bone and muscle mass $(1,2)$, carbohydrate, fat, and protein metabolism (3), sexual maturation (4), and insulin resistance (5). Several in vitro and in vivo studies also demonstrate GH involvement in immune regulation, and the GH receptor is expressed by several leukocyte subpopulations (6). GH mediates thymic development (7), promotes 
$\mathrm{T}$ cell engraftment in severe combined immunodeficiency mice (8), improves B cell responses and antibody production $(9,10)$, and modulates NK cell (11) and macrophage activity (12) as well as in vivo Th1/Th2 and humoral immune responses (13). Some reports describe beneficial effects of $\mathrm{GH}$ administration in autoimmunity. GH administration and neutralization of TNF $\alpha$ reduce mucosal inflammation in experimental colitis (14); by altering tolerization mechanisms such as the cytokine environment, macrophage polarization, activation of the suppressor T cell population, and Th17 cell plasticity, GH also reduces type I diabetes development (15).

Rheumatoid arthritis (RA) is the most prevalent inflammatory autoimmune disease worldwide. Its main clinical feature is chronic inflammation in joints, associated with bone and cartilage destruction (16). The RA spectrum and disease progression are governed by immune, genetic, and environmental factors (17). Its origin nonetheless lies in an inappropriate inflammatory reaction derived from deregulation of the adaptive and/or innate branches of the immune response. During RA development, there is active proliferation of endothelial cells and synovial fibroblasts; the synovium displays features of chronic inflammation, including massive leukocyte infiltration of innate (macrophages, $\mathrm{NK}$, and dendritic cells; DC) and adaptive (CD4 ${ }^{+} \mathrm{T}$ and $\mathrm{B}$ cells) immune response cells (16).

Using collagen-induced arthritis (CIA) as a model of RA, we observed that $\mathrm{GH}$ transgenic (GHTg) mice were protected against disease development, whose onset was delayed and severity reduced. Our data demonstrated an inhibitory role of GH in the induction phase of the disease. The anti-collagen response was severely impeded in GHTg mice, as was the synthesis of inflammatory cytokines, suggesting impairment of Th17/ Th1 cell plasticity toward a pathological phenotype. GH also modulated the CIA progression phase, shown by reduced severity of established disease in collagen-immunized DBA/1J mice following exogenous $\mathrm{GH}$ administration. Our data demonstrate that $\mathrm{GH}$ administration ameliorates CIA symptoms pointing out an important role of this hormone tuning the immune response. Altogether, our results underline the interrelationship between the endocrine and the immune systems that regulate the immune response and support a potential use of endogenous endocrine mediators for the treatment of inflammatory and autoimmune diseases.

\section{MATERIALS AND METHODS}

\section{Mice}

Mice transgenic for bovine GH (bGH) under the control of the phosphoenolpyruvate carboxykinase promoter on a C57BL/6J background (18) were maintained by continuous backcrosses on C57BL/6J females. 35 transgenic mice (GHTg) and 33 control littermates (10-14 weeks old) were used, with matched sex ratios in each experiment. DBA/1J mice (50 males) were obtained from Charles River Laboratories International. Three OVA-specific TCR-transgenic mice (OT-II) were donated by Dr. C. Ardavín (Centro Nacional de Biotecnología, Madrid, Spain). Mice were handled according to national and European Union guidelines, and experiments were approved by the Comité Ético de Experimentación Animal, Centro Nacional de Biotecnología/ CSIC and the Regional Government (PROEX 250-16).

\section{CIA Induction and Treatment}

Two-month-old GHTg mice, control littermates, or DBA/1J mice were immunized intradermally (i.d.) at the tail base with an emulsion of chicken type II collagen (CII) in citrate buffer and Freund's complete adjuvant (19). Arthritis was assessed daily by scoring each limb on a $0-4$ scale, where $0=$ normal, $1=$ erythema and mild swelling confined to the tarsals or ankle joint, $2=$ erythema and mild swelling extending from the ankle to the tarsals, 3 = erythema and moderate swelling extending from the ankle to metatarsal joints, and $4=$ erythema and severe swelling encompassing the ankle, foot, and digits, or ankylosis of the limb, yielding a maximum score of 16 per mouse. In some cases, on appearance of the first signs of CIA (score $\sim 2=$ day 0 ), affected $\mathrm{DBA} / 1 \mathrm{~J}$ mice were separated into two groups; one group received a daily subcutaneous (s.c.) rhGH injection $(2 \mu \mathrm{g} / \mathrm{ml}, 200 \mu \mathrm{l}$, Genotonorm, Pfizer) until day 9 and the other received only PBS as control. Clinical scores $\left(\mathrm{Cs}_{\mathrm{t}}\right)$ were re-evaluated daily.

\section{Histochemistry}

At the end of the experiments, the score was monitored and paws removed, fixed in $4 \%$ formalin, decalcified with $500 \mathrm{mM}$ EDTA (Sigma) at $4^{\circ} \mathrm{C}$, and paraffin embedded. Sections $(7-\mu \mathrm{m}$ thick) were hematoxylin/eosin-stained. When needed, safranin $\mathrm{O} /$ light green and fast green or TRAP staining were carried out using a leukocyte acid phosphatase staining kit (Sigma-Aldrich). Sections were analyzed in an Olympus BX51 microscope equipped with a digital camera (Olympus DP70).

\section{Cell Purification and Flow Cytometry}

To prepare single-cell suspensions, spleens and lymph nodes (LNs) were harvested and minced on a $40-\mu \mathrm{m}$ nylon mesh in RPMI 1640 medium (Lonza) supplemented with 10\% fetal bovine serum (FBS), $2 \mathrm{mM}$ L-glutamine, and $50 \mu \mathrm{g} / \mathrm{ml}$ penicillin/ streptomycin. Erythrocytes were lysed with VersaLyse (Beckman Coulter). Single-cell suspensions of lymphoid organs or blood leukocytes were prepared and blocked with anti-CD16/32 (BD Pharmingen) to impede nonspecific Fc-mediated antibody binding. Samples were stained with antibody conjugates by a standard procedure, using FITC anti-CD25, FITC anti-CD11b, SPRD (Spectral Red) anti-Gr1 (Pharmingen), SPRD anti-CD4 and PE-Cyan 5 anti-F4/80 (BM8) (eBiosciences), FITC anti-CD8, -CD69, -CD45, APC (allophycocyanin) anti-B220 (Beckman Coulter), and PE (phycoerythrin) anti-CD86 (BioLegend). FoxP3, IL-10, IL-17, GM-CSF, IFN $\gamma$, and TNF $\alpha$ expression was determined after permeabilization and intracellular staining with a PE-labeled antibody (FoxP3 staining set; eBiosciences), FITC-labeled antibody to IL-10 (JES516E3, Pharmingen) and to GM-CSF (MP1-22E9, eBiosciences), and PE-labeled antibody to IL17 (TC11-18H10, Pharmingen), PE-Cyan7-labeled antibody to TNF $\alpha$ (MP6-xt3, eBiosciences), and APC-labeled antibody to IFN $\gamma$ (XMG1.2, R\&D Systems).

For in vitro characterization of $\mathrm{CD}^{+}$and $\mathrm{CD}^{+} \mathrm{T}$ cell subpopulations in the LNs of GHTg and control mice, $1 \times 10^{6}$ cells $/ \mathrm{ml}$ were cultured $\left(4 \mathrm{~h}, 37^{\circ} \mathrm{C}, 5 \% \mathrm{CO}_{2}\right)$ in RPMI supplemented with 
10\% FBS, $50 \mathrm{ng} / \mathrm{ml}$ PMA (Sigma), and $500 \mathrm{ng} / \mathrm{ml}$ ionomycin (Sigma). For intracellular staining, $2.5 \mu \mathrm{M}$ monensin (Sigma) was added after 60 min of culture. Cells were then fixed with $2 \%$ paraformaldehyde and permeabilized with $0.2 \%$ Saponin (Sigma) prior to be stained with the appropriated antibodies.

For the analysis of LNs in GH-treated arthritic DBA/1J mice and controls, $5 \times 10^{6}$ cells $/ \mathrm{ml}$ were cultured $\left(5 \mathrm{~h}, 37^{\circ} \mathrm{C}, 5 \% \mathrm{CO}_{2}\right)$ in RPMI supplemented with 10\% FBS, $5 \mathrm{ng} / \mathrm{ml}$ PMA (Sigma), $500 \mathrm{ng} / \mathrm{ml}$ ionomycin (Sigma), $25 \mu \mathrm{M}$ TAPI-1 (Enzo), GolgiStop and GolgiPlug (BD Pharmingen). Cells were fixed and stained according to the manufacturer's instructions. For intracellular staining of FoxP3, we employed the FoxP3/transcription factor staining buffer set (eBiosciences) and we used the Cytokine BD kit BD Pharmingen for the rest of cytokines evaluated.

When required, cells isolated from LNs were cultured ( $48 \mathrm{~h}$, $\left.37^{\circ} \mathrm{C}, 5 \% \mathrm{CO}_{2}\right)$ in plates coated with anti-CD3 (100 ng/ml, $4 \mathrm{~h}$, $37^{\circ} \mathrm{C}$; clone $145-2 \mathrm{C} 11$, BioLegend). IFN $\gamma$ and IL-7 levels were determined in culture supernatants using the ELISA MAX sets (BioLegend).

When necessary, murine naïve B cells were purified from spleen using mouse pan-B Dynabeads (Invitrogen). Batches with $>95 \%$ purity were activated with $5 \mu \mathrm{g} / \mathrm{ml}$ goat anti-mouse IgM Ab (Jackson ImmunoResearch; $6 \mathrm{~h}, 37^{\circ} \mathrm{C}$ ) or $5 \mu \mathrm{g} / \mathrm{ml} \mathrm{LPS}$ (lipopolysaccharide from Escherichia coli serotype 055:B5; Sigma;
$6 \mathrm{~h}, 37^{\circ} \mathrm{C}$ ), alone or with exogenous recombinant human $\mathrm{GH}$ (rhGH, $5 \mu \mathrm{g} / \mathrm{ml}$, Genotonorm; Pfizer). Stained samples as above were analyzed on a flow cytometer (Cytomics FC 500; Beckman Coulter). FACS data were analyzed using the FlowJo (FlowJo LLC) and CytoSpec (Germany) software.

\section{Bone Marrow Dendritic Cell (BM-DC) Differentiation}

Bone marrow dendritic cell from GHTg or control littermates were obtained from bone marrow cell suspensions treated with erythrocyte lysis buffer and cultured in 150-mm Petri dishes in complete RPMI 1640 medium supplemented with 10\% FCS and $20 \mathrm{ng} / \mathrm{ml}$ recombinant granulocyte-macrophage colony-stimulating factor (PeproTech) (20). Immature BM-DC were collected on day 8 and purity evaluated by flow cytometry using anti-CD11c-FITC and -MHCII-PE Ab (BD Pharmingen). Batches of $>95 \%$ purity were used for maturation with LPS $\left(1 \mu \mathrm{g} / \mathrm{ml}, 12 \mathrm{~h}, 37^{\circ} \mathrm{C}\right)$.

\section{In Vitro Induction of Immune Synapse (IS) Formation Between DC and CD4 T Cells} Immune synapse formation between mouse BM-DC and OT-II CD4 ${ }^{+} \mathrm{T}$ cells was induced as reported $(21,22)$. Briefly, mature BM-DC $\left(1 \mu \mathrm{g} / \mathrm{ml} \mathrm{LPS}, 12 \mathrm{~h}, 37^{\circ} \mathrm{C}\right)$ were loaded with

TABLE 1 | PCR primer sequences.

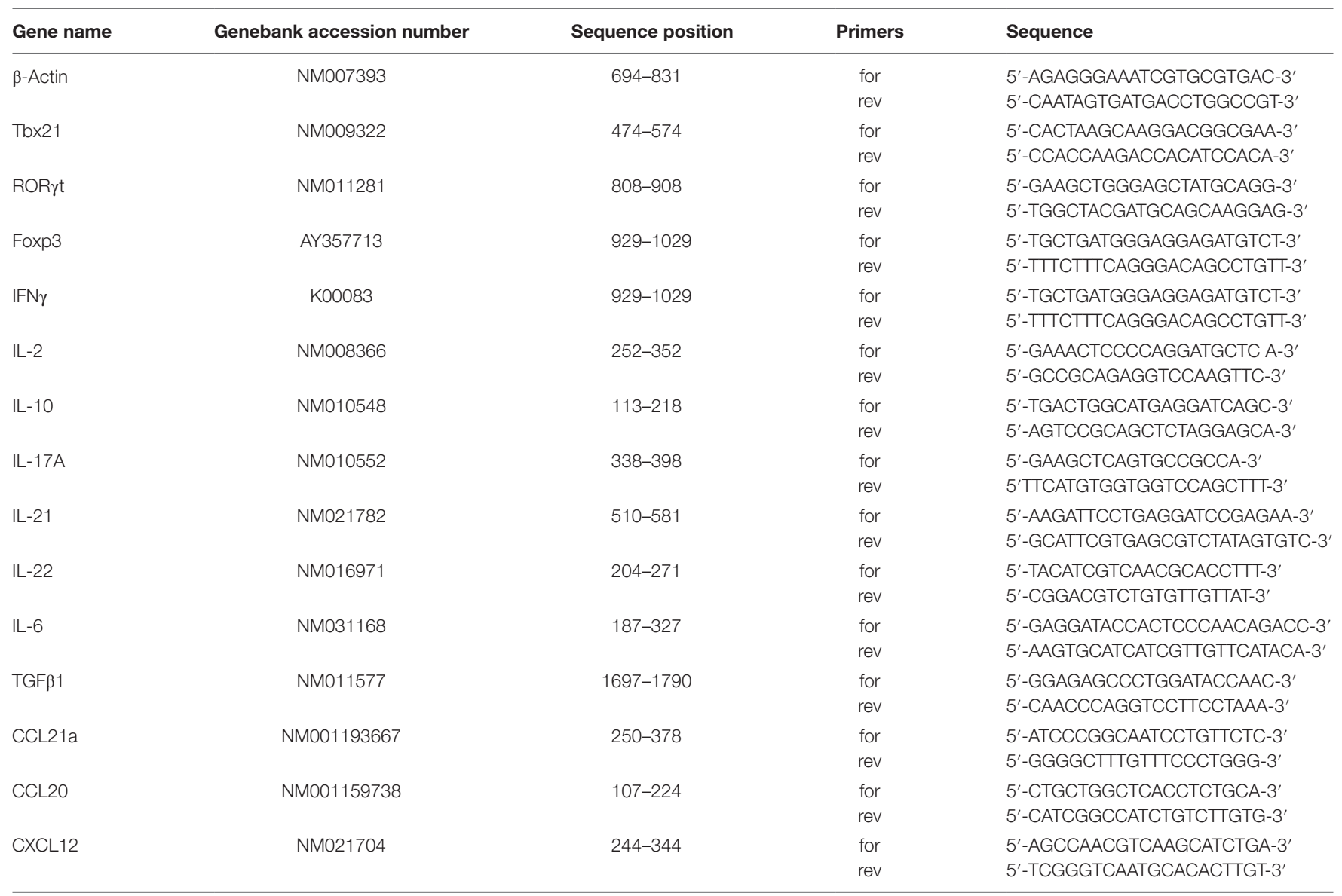

Primer sequences employed for PCR detection of several factors involved in the differentiation and function of Th17, Th1, or Treg subsets, as well as for $\beta$-actin (housekeeping gene). 
$\mathrm{OVA}_{323-339}$-peptide $\left(5 \mu \mathrm{M}, 30 \mathrm{~min}, 37^{\circ} \mathrm{C}\right.$; GenScript) and mixed in complete medium (RPMI 1640, 10\% FCS) with CD4 ${ }^{+} \mathrm{T}$ cells (1:5 DC:CD4 ${ }^{+}$T cells) from OT-II mouse spleen and LNs, purified with a mouse $\mathrm{T}$ cell negative isolation kit (MACS; Miltenyi Biotec; T cell purity was routinely $>97 \%$ ). Cells were centrifuged $(120 \times \mathrm{g}, 2 \mathrm{~min})$ in a conical tube and incubated in complete medium $\left(15-30 \mathrm{~min}, 37^{\circ} \mathrm{C}\right)$ to foster IS formation.

\section{T Cell Proliferation}

OT-II CD $4^{+} \mathrm{T}$ cells were labeled with CellTrace Violet $(0.5 \mu \mathrm{M}$, $30 \mathrm{~min}, 37^{\circ} \mathrm{C}$; Molecular Probes) and added to plates containing OVA peptide-loaded BM-DC $\left(3 \times 10^{4} \mathrm{DC} / 6 \times 10^{4} \mathrm{~T}\right.$ cells $)$. Cells were co-cultured in RPMI 1640 with $10 \%$ FCS $(24,48$, or 72 h), and proliferation determined by flow cytometry using dye dilution evaluation in a Gallios flow cytometer (Beckman Coulter). The percentage of dividing cells was calculated using the FlowJo. When needed, $5 \mu \mathrm{g} / \mathrm{ml} \mathrm{rhGH}$ was added.

\section{Enzyme-Linked Immunoassay}

Microtiter plates were coated with chicken type II collagen in PBS $\left(5 \mu \mathrm{g} / \mathrm{ml} ; 90 \mathrm{~min}, 37^{\circ} \mathrm{C}\right)$. After blockade of free protein-binding sites with $0.5 \% \mathrm{BSA} / \mathrm{PBS}$, plates were incubated with serial dilutions of serum samples from immunized mice, followed by peroxidaselabeled subclass-specific rabbit anti-mouse antisera (Dako).

\section{Semiquantitative Real-Time PCR}

cDNA sequences were obtained from the GenBank database. PCR primers were designed from the cDNA sequences using Primer-BLAST software (Table 1). RNA (5 $\mu \mathrm{g}$ ) was used for reverse transcription. cDNA was obtained by SuperScript II reverse transcriptase (Invitrogen). cDNA was then amplified by PCR using Power SYBR Green PCR Master Mix (Applied Biosystems) and $0.3 \mu \mathrm{M}$ of primers. Triplicate samples were quantified using the ABI Prism HT7900 sequence detection system (Applied Biosystems). For relative quantification, we used the equation $2^{-\Delta \mathrm{Ct}}$. Each sample was normalized with $\beta$-actin $(\Delta \mathrm{Ct})$ and the respective basal levels in the spleen of wild-type (wt) mice $(\Delta \Delta \mathrm{Ct})$.

\section{Statistical Analysis}

Statistical analyses were performed using GraphPad Prism 5.0 software (GraphPad). Unpaired Student's $t$-test, Mann-Whitney $U$-test, and two-way ANOVA were used as indicated (in all cases, $\left.{ }^{\star} p \leq 0.05,{ }^{* *} p \leq 0.01,{ }^{* *} p \leq 0.001\right)$.

\section{RESULTS}

\section{GHTg Mice Are Protected Against CIA}

To analyze the effect of $\mathrm{GH}$ in immune response regulation, we tested its effect in a murine model of CIA on a mouse strain transgenic for bGH under the control of the rat phosphoenolpyruvate carboxykinase promoter; these mice showed constant circulating $\mathrm{GH}(\sim 5 \mu \mathrm{g} / \mathrm{ml})(18)$. The CIA model allows the study of the priming phase of the disease, which consists of activation of the collagen type II-specific immune response as well as the inflammatory effector phase, characterized by local inflammation, and cartilage and joint destruction (23). GHTg mice were partially protected, and developed arthritis at a lower incidence compared to wt arthritic control littermates (GHTg vs. wt, 0 vs. $45 \%$ at day 30,20 vs. $70 \%$ at day 35). The GHTg mice also showed delayed disease onset (GHTg, day 33 vs. wt, day 21) (Figure 1A) concomitant with a marked decrease in CIA severity (Figure 1B), as shown by evaluation of the incidence and clinical score. Consistent with these results, histopathological examination at day 30 highlighted a marked reduction in synovial inflammation, pannus formation, erosion of articular cartilage in GHTg vs. control arthritic mice, and presence of osteoclasts in the joints of wt mice (Figures 2A-C).

In accordance with a previous report (19), we detected low IgG1 levels in wt arthritic mice, while IgG2 was the predominant isotype in late disease phase (day 25). IgG1 and IgG2 responses were nonetheless equally reduced in GHTg mice (Figure 2D). The lesser severity of CIA symptoms in GHTg mice was associated with changes in anti-collagen type II antibody levels. Anti-collagen IgM and IgG antibody levels were significantly lower in GHTg mice relative to wt arthritic mice, which suggests that $\mathrm{GH}$ triggered protection during the induction phase of the disease (Figure 2D).

As reported (13), flow cytometry analysis showed that in basal conditions compared to controls, GHTg mice had a significantly higher proportion of $\mathrm{B} 220^{+}$cells in LNs and reduced percentage of $\mathrm{CD}^{+}$and $\mathrm{CD}^{+} \mathrm{T}$ cells, whereas no variations were found in the percentage of immune cell populations either in blood or in
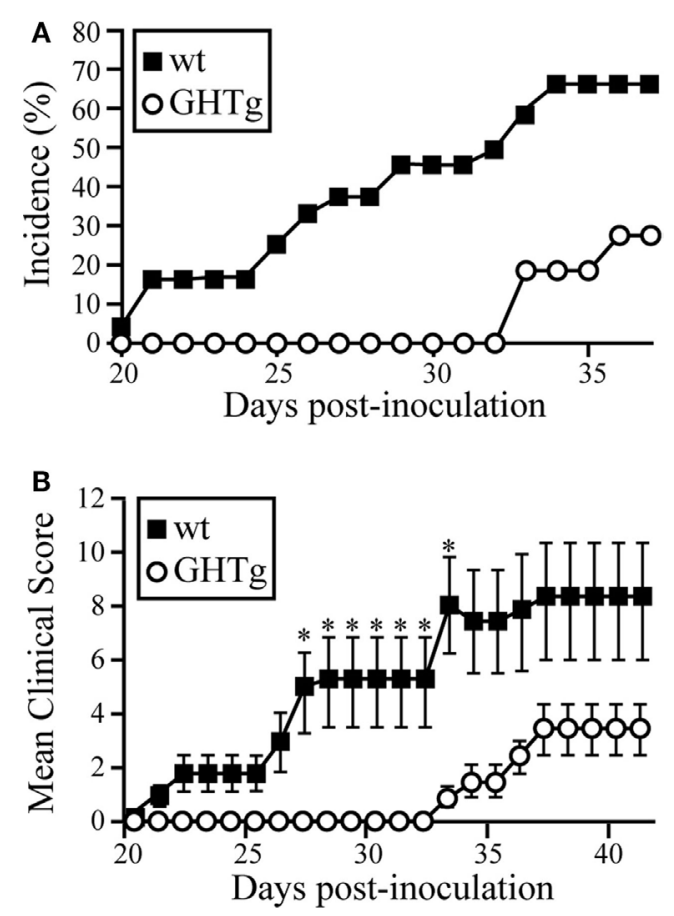

FIGURE 1 | GHTg mice are resistant to collagen-induced arthritis. One representative experiment is shown of three performed ( $n=11 \mathrm{mice} / \mathrm{group}$ ). (A) Cumulative incidence of arthritic symptoms in wild-type (wt) and GHTg mice after immunization with chicken type II collagen. (B) Clinical scores in affected wt and GHTg mice. Data shown as mean \pm SEM (Student's $t$-test, $\left.{ }^{*} p \leq 0.05\right)$. Two-way ANOVA shows significant differences for time $(p=0.0217)$ and genotype $(p<0.0001)$ factors. 

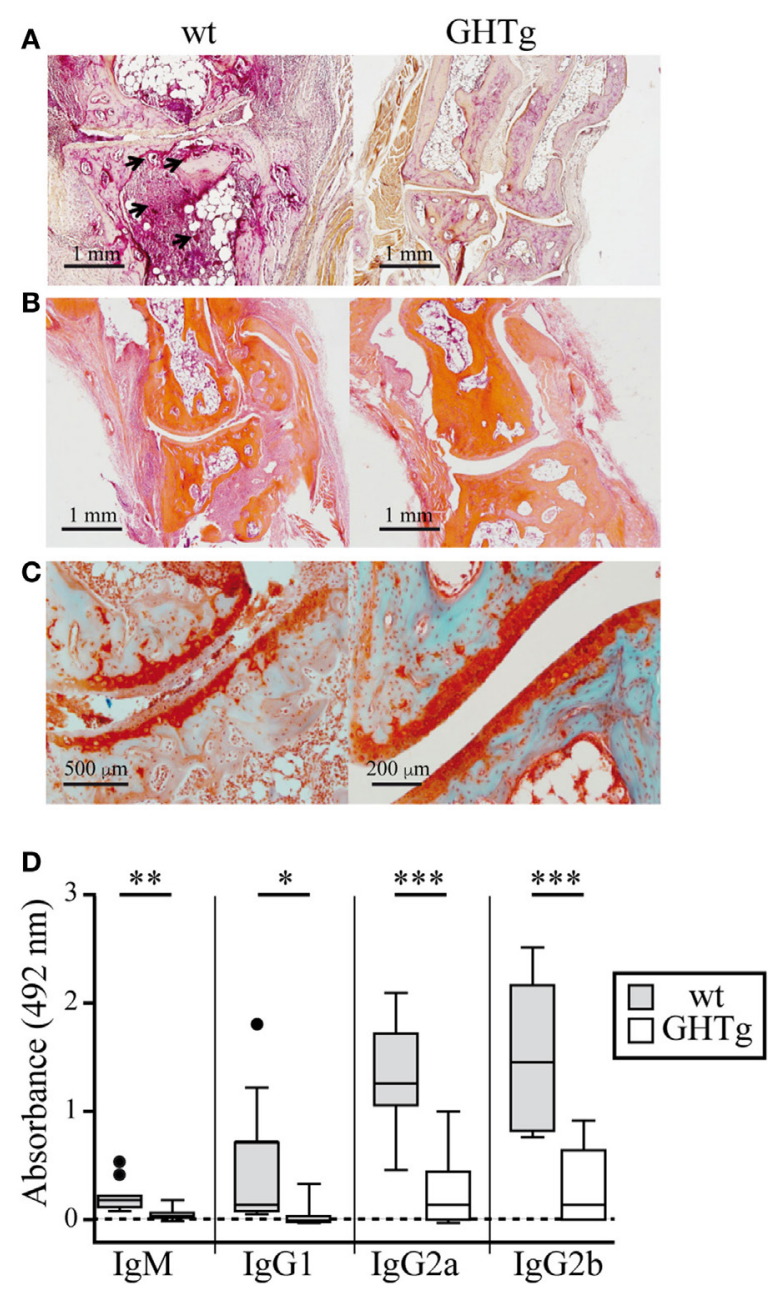

FIGURE 2 | Histological comparison in cartilage and bone of collagenimmunized wild-type (wt) and GHTg mice. Representative images at day 30 post-inoculation. (A) Acid phosphatase reaction in formaldehyde-fixed paraffin embedded joint sections showing osteoclasts (arrows).

(B) Hematoxylin/eosin staining shows pannus only in the wt sample.

(C) Safranin-light green staining shows no evidence of cartilage degradation in the GHTg mouse sample. (A,B) Original magnification, 2.5× (bar, $1 \mathrm{~mm}$ );

(C) $5 \times$ (left; bar, $500 \mu \mathrm{m}$ ), 10x (right; bar, $200 \mu \mathrm{m}$ ). (D) Isotype-specific ELISA to detect anti-chicken collagen II antibodies in sera from the immunized mice. Individual values are shown for sera diluted 1/200, except for IgG2b

$(1 / 1,000)$. Tukey boxplot showing median and 1.5 interquartile range. Student's $t$-test $\left({ }^{\star} p \leq 0.05,{ }^{\star \star} p \leq 0.01,{ }^{\star \star *} p \leq 0.001\right)$. spleen (Table 2). When evaluated different subpopulations of T cells we did not detect differences (Table 3). Previous reports suggest a role for $\mathrm{GH}$ in modulating the immune response $(10,12,13,15)$; we thus characterized immune cell subsets in blood and peripheral LNs from collagen-immunized GHTg mice and wt littermates. Flow cytometry analysis showed that, compared to controls, immunized GHTg mice had a significantly larger number of $\mathrm{B}_{2} 20^{+}$cells in peripheral LNs (Table 4). In agreement with a previous report (15), GH did not affect in vitro $B$ cell activation by either anti-mouse IgM antibodies or LPS (Figure 3), which rules out intrinsic in vitro activation defects of GHTg mouse B cells. The immunized GHTg mice also had significant lower percentage of $\mathrm{CD}^{+} \mathrm{IFN} \gamma^{+}$and of $\mathrm{CD}^{+} \mathrm{IFN} \gamma^{+}$ cells and a marked tendency to higher proportion of $\mathrm{CD}^{+}{ }^{+} \mathrm{FoxP} 3^{+}$ cells compared to control littermates (Table 5). These data suggest differences in $\mathrm{T}$ cell polarization between both groups of mice.

To evaluate the $\mathrm{GH}$ effect on antigen presentation to T cells, we treated BM-DC derived from GHTg mice or wt controls in vitro with LPS and loaded the cells with $\mathrm{OVA}_{323-339}$-peptide. Cells were then mixed, alone or with rhGH, with OT-II mouse $\mathrm{CD}^{+}$cells purified by negative selection and labeled with CellTrace Violet. Flow cytometry detection of cell tracker dilution after 48 and $72 \mathrm{~h}$ co-culture showed similar OT-II T cell proliferation in all conditions analyzed (Figure 4A); no differences were observed in $\mathrm{CD}^{+} \mathrm{T}$ cell activation markers (CD25, CD69, CD62L) (Figures 4B-D). These results suggest that antigen-presenting cells from GHTg and control littermates have similar antigenpresenting capacity to $\mathrm{CD}^{+} \mathrm{T}$ cells and that exogenous rhGH does not affect responder $\mathrm{CD} 4^{+} \mathrm{T}$ cell proliferation.

\section{GH Regulates the Th17 and Th1 Profiles}

Rheumatoid arthritis has long been considered a Th1-mediated disease, but considerable evidence shows a key role for proinflammatory Th17 cells in inflammation and joint destruction $(24,25)$. IL-17 levels are high in serum and synovial tissue of RA patients (26). IL-17-deficient allogenic bone marrow transplant in mice prevents CIA and reduces disease severity (27). We thus characterized the Th17 profile in CIA mouse LNs at day 37 post-inoculation. Immunized GHTg mice showed a significant reduction in ROR $\gamma \mathrm{t}$, IL-17, GM-CSF, and IL-22 mRNA expression compared to control arthritic littermates, whereas there were no differences in IL-21, IL-6, or IL-2 mRNA levels in peripheral LNs (Figure 5A). These results indicate that $\mathrm{GH}$ reduced the pathogenic profile of the Th17 response. In arthritic GHTg vs. wt

TABLE 2 | Distribution of cell populations in wild-type (wt) and GHTg mice.

\begin{tabular}{|c|c|c|c|c|c|c|}
\hline & \multicolumn{2}{|c|}{ Spleen } & \multicolumn{2}{|c|}{ Peripheral lymph nodes (LNs) } & \multicolumn{2}{|c|}{ Blood } \\
\hline & wt & GHTg & wt & GHTg & wt & GHTg \\
\hline $\mathrm{CD}^{+}$ & $20.4 \pm 5.8$ & $17.6 \pm 4.5$ & $32.6 \pm 0.9$ & $21.5 \pm 1.7^{\star \star}$ & $15.7 \pm 0.5$ & $11.3 \pm 0.4$ \\
\hline $\mathrm{CD}^{+}$ & $17.4 \pm 2.1$ & $12.8 \pm 2.1$ & $32.3 \pm 1.0$ & $25.1 \pm 1.5^{\star}$ & $16.3 \pm 1.9$ & $13.6 \pm 2.0$ \\
\hline $\mathrm{B} 22 \mathrm{O}^{+}$ & $68.6 \pm 2.2$ & $66.1 \pm 2.1$ & $28.6 \pm 2.2$ & $48.8 \pm 0.6^{\star \star \star}$ & $46.7 \pm 1.8$ & $53.8 \pm 2.4$ \\
\hline CD11b+ & $14.9 \pm 1.0$ & $16.0 \pm 0.2$ & $10.7 \pm 2.8$ & $13.2 \pm 3.2$ & $29.8 \pm 6.4$ & $20.7 \pm 2.2$ \\
\hline $\mathrm{GR}^{+}+$ & $1.3 \pm 0.3$ & $2.6 \pm 0.5$ & $0.3 \pm 0.1$ & $0.6 \pm 0.3$ & $8.4 \pm 0.8$ & $11.4 \pm 1.7$ \\
\hline
\end{tabular}

Distribution of cell populations in blood, spleen, and peripheral LNs of 12-week-old wt and GHTg mice. Numbers correspond to the percentage of positive cells \pm SD indicated ( $n=3)$. Bold numbers highlight significant differences between GHTg and control mice, as indicated.

Student's t-test, ${ }^{*} p<0.05,{ }^{* *} p<0.01,{ }^{* * *} p<0.001$. 
mice, we also found significantly lower levels of Tbx21 mRNA, the master regulator of the Th1 subset (Figure 5B). These data correlated with a marked reduction in IFN $\gamma$ mRNA levels in GHTg relative to wt mice. We also found significant higher levels of TGF $\beta$ in GHTg mice (Figure 5A), although we did not observed differences in FoxP3 and in IL-10 mRNA levels between the two mouse groups (Figure 5B). We nonetheless observed a

TABLE 3 | Distribution of $\mathrm{CD}^{+} / \mathrm{CD}^{+}$and $\mathrm{CD}^{+} / \mathrm{CD}^{+}$cell populations in nonimmunized wild-type (wt) and GHTg mice.

\begin{tabular}{cccc}
\hline & \multicolumn{2}{c}{ Peripheral lymph nodes (LNs) } \\
\cline { 3 - 4 } & & \multicolumn{1}{c}{ wt } & GHTg \\
\hline $\mathrm{CD}^{+}$ & $\mathrm{Foxp3}^{+}$ & $10.75 \pm 1.48$ & $16.83 \pm 2.17$ \\
& $\mathrm{IFN} \gamma^{+}$ & $21.10 \pm 6.93$ & $21.40 \pm 1.85$ \\
& $\mathrm{IL}-17^{+}$ & $0.335 \pm 0.205$ & $1.113 \pm 0.340$ \\
$\mathrm{CD} 8^{+}$ & $\mathrm{IFN} \gamma^{+}$ & $16.30 \pm 5.66$ & $23.73 \pm 9.59$ \\
& $\mathrm{IL}-17^{+}$ & $0.385 \pm 0.262$ & $0.758 \pm 0.299$
\end{tabular}

Distribution of cell populations in peripheral LNs of wt and GHTg mice. Numbers correspond to percentage of positive cells $\pm S D$ values $(n=3)$. tendency to higher FoxP3/ROR $\gamma$ T ratio when comparing GHTg $(0.59 \pm 0.06)$ with controls $(0.32 \pm 0.05)$. These results confirmed the milder disease observed in GHTg mice and support the beneficial effect of GH.

\section{Therapeutic GH Administration Reduces Disease Severity in CIA Mice}

We used the CIA model in DBA/1J mice to assess the potential therapeutic use of GH administration. Arthritis was induced by i.d. injections of collagen type II into 2-month-old mice. On appearance of the first CIA signs (score $\sim 2=$ day 0 ), affected mice were divided into two groups; one received a daily s.c. GH injection until day 10 and the other received PBS as control. CIA progression was delayed in GH-relative to PBS-treated arthritic mice (Figure 6A); this effect was observed as early as 2 days after initiation of treatment and reached a maximum at 6 days. The number of affected paws increased with time in PBS-treated arthritic mice, but GH-treated mice showed no variation (Figure 6B). GH treatment did not alter anti-collagen IgM and IgG antibody levels in arthritic DBA/1J mouse serum (Figure 6C). These data suggest

TABLE 4 | Distribution of cell populations in immunized wild-type (wt) and GHTg mice.

\begin{tabular}{|c|c|c|c|c|c|c|c|c|}
\hline & \multicolumn{2}{|c|}{ Spleen } & \multicolumn{2}{|c|}{ Peripheral lymph nodes (LNs) } & \multicolumn{2}{|c|}{ Mesenteric LNs } & \multicolumn{2}{|c|}{ Blood } \\
\hline & wt & GHTg & wt & GHTg & wt & GHTg & wt & GHTg \\
\hline $\mathrm{CD}^{+}$ & $33.7 \pm 1.2$ & $33.8 \pm 4.8$ & $51.7 \pm 13.2$ & $43.2 \pm 9.7$ & $64.8 \pm 3.3$ & $56.1 \pm 6.4$ & $28.2 \pm 4.2$ & $22.4 \pm 2.2$ \\
\hline $\mathrm{CD}^{+}{ }^{+}$ & $19.4 \pm 2.6$ & $22.5 \pm 10.7$ & $27.9 \pm 6.5$ & $25.9 \pm 5.2$ & $38.2 \pm 1.7$ & $36.7 \pm 4.1$ & $15.3 \pm 2.5$ & $12.7 \pm 1.1$ \\
\hline $\mathrm{CD}^{+}$ & $19.0 \pm 1.3$ & $17.9 \pm 3.4$ & $23.4 \pm 6.5$ & $16.4 \pm 4.9$ & $28.9 \pm 3.1$ & $21.5 \pm 4.5$ & $10.5 \pm 4.0$ & $8.5 \pm 0.9$ \\
\hline $\mathrm{B}^{2} 2 \mathrm{O}^{+}$ & $54.1 \pm 5.3$ & $50.8 \pm 6.7$ & $35.4 \pm 4.7$ & $54.0 \pm 8.3^{*}$ & $34.8 \pm 3.7$ & $41.7 \pm 7.0$ & $65.2 \pm 3.9$ & $68.8 \pm 3.9$ \\
\hline $\mathrm{NK} 1^{+}$ & $1.9 \pm 0.7$ & $1.5 \pm 0.5$ & $0.9 \pm 0.3$ & $1.0 \pm 0.2$ & $0.8 \pm 0.1$ & $1.2 \pm 0.1$ & $2.5 \pm 0.8$ & $2.6 \pm 0.9$ \\
\hline CD11b+ & $5.3 \pm 1.9$ & $6.6 \pm 3.7$ & $4.7 \pm 1.3$ & $6.5 \pm 2.0$ & $7.7 \pm 2.3$ & $13.1 \pm 2.0$ & $20.5 \pm 5.6$ & $24.4 \pm 7.2$ \\
\hline $\mathrm{GR} 1^{+}$ & $5.5 \pm 1.5$ & $7.5 \pm 3.8$ & $6.6 \pm 1.3$ & $8.2 \pm 0.9$ & $8.0 \pm 1.6$ & $12.4 \pm 1.0$ & $15.8 \pm 4.0$ & $17.5 \pm 5.0$ \\
\hline $\mathrm{F} 4 / 80^{+}$ & $4.7 \pm 0.8$ & $6.1 \pm 2.0$ & $0.9 \pm 0.4$ & $1.1 \pm 0.8$ & $2.9 \pm 1.4$ & $5.4 \pm 0.8$ & $6.7 \pm 3.0$ & $9.8 \pm 5.8$ \\
\hline
\end{tabular}

Distribution of cell populations in blood, spleen, and peripheral LNs of collagen type Il-immunized wt and GHTg mice. Numbers correspond to percentage of positive cells \pm SD values $(n=3)$. Bold numbers highlight significant differences between GHTg and control mice, as indicated.

Student's t-test, * $p<0.05$.
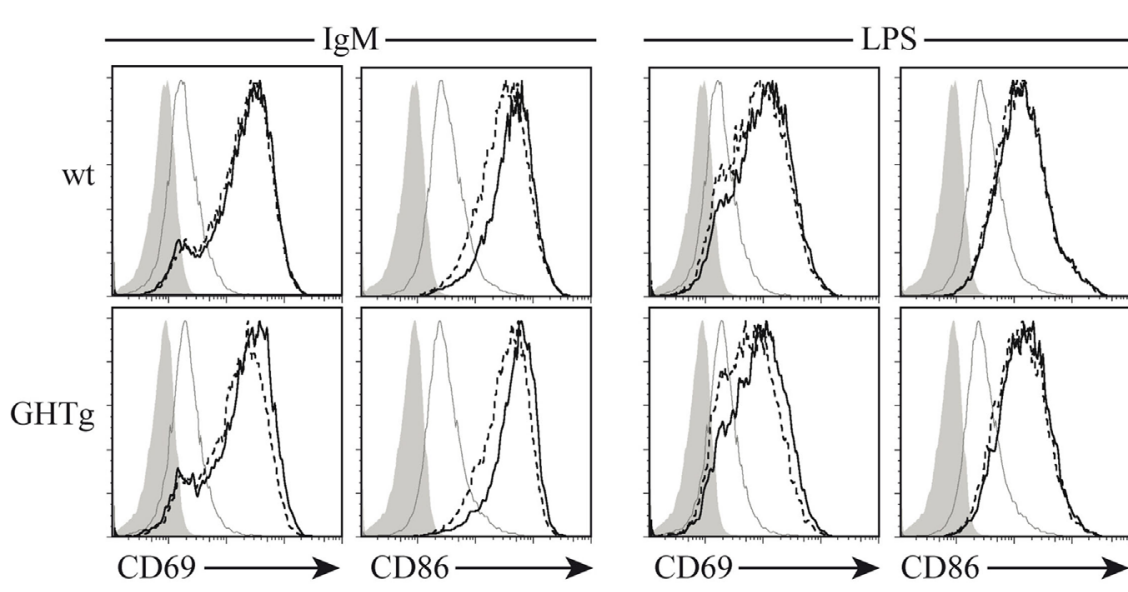

\section{Isotype}

- unstimulated

- IgM or LPS

..... IgM or LPS $+\mathrm{GH}$

FIGURE 3 | Growth hormone (GH) does not alter B-cell activation in vitro. Splenic B cells from wild-type (wt) and GHTg mice were unstimulated or incubated (6 h, $\left.37^{\circ} \mathrm{C}\right)$ with anti-lgM antibody or LPS alone or with exogenous rhGH $(5 \mu \mathrm{g} / \mathrm{ml})$. The activation level was determined using anti-CD69 and anti-CD86 $\mathrm{mAb}$ in flow cytometry. One representative experiment of three is shown. 
that, in addition to its role in the induction phase of the disease, $\mathrm{GH}$ can hinder experimental arthritis progression.

Growth hormone treatment reduced ROR $\gamma \mathrm{t}$, IL-17, and IL-22 mRNA expression in LNs at day 10 (Figure 6D). We also detected lower Tbx21 and IFN $\gamma$ levels in GH-compared to PBStreated CIA mice, whereas IL-10 levels increased (Figure 6D). When, in the same samples, the expression levels of chemokines were evaluated, we found in $\mathrm{GH}$-treated mice, similar levels of

TABLE 5 | Distribution of $\mathrm{CD}^{+} / \mathrm{CD}^{+}+$and $\mathrm{CD}^{+} / \mathrm{CD}^{+}$cell populations in immunized wild-type (wt) and GHTg mice.

\begin{tabular}{cccc}
\hline & & \multicolumn{2}{c}{ Peripheral lymph nodes (LNs) } \\
\cline { 3 - 4 } & & wt & GHTg \\
\hline $\mathrm{CD}^{+}$ & $\mathrm{Foxp3}^{+}$ & $10.80 \pm 1.99$ & $13.55 \pm 0.35$ \\
& $\mathrm{IFN \gamma} \gamma^{+}$ & $\mathbf{1 4 . 7 7} \pm \mathbf{3 . 7 4}$ & $\mathbf{1 0 . 4 5} \pm \mathbf{2 . 7 6}$ \\
& $\mathrm{IL}-17^{+}$ & $0.2267 \pm 0.0115$ & $0.3850 \pm 0.0636$ \\
$\mathrm{CD} 8^{+}$ & $\mathrm{IFN} \gamma^{+}$ & $\mathbf{1 9 . 2 3} \pm \mathbf{2 . 0 0 3}$ & $\mathbf{1 3 . 4 5} \pm \mathbf{0 . 2 1 2 \mathbf { 1 } ^ { * }}$ \\
& $\mathrm{IL}-17^{+}$ & $0.3667 \pm 0.155$ & $0.28 \pm 0.0424$
\end{tabular}

Distribution of cell populations in peripheral LNs of collagen type Il-immunized wt and GHTg mice. Numbers correspond to percentage of positive cells $\pm S D$ values $(n=3)$. Bold numbers highlight significant differences between GHTg and control mice, as indicated.

Student's t-test, ${ }^{*} p<0.05$. homeostatic chemokines, CCL21 and CXCL12, and a significant reduction of the inflammatory chemokine CCL20 (Figure S1 in Supplementary Material). CCL20 is a key chemokine for Th17 cell movement (28). These data, in line with the results for GHTg arthritic mice, suggested that exogenous rhGH promoted Th17 cell repolarization to a non-pathogenic profile or, alter natively, blocked Th17 polarization to a Th1 phenotype. The analysis of these cells in the LNs of GH-treated CIA mice confirmed these observations. Among $\mathrm{CD}^{+}{ }^{+} \mathrm{T}$ cells, $\mathrm{GH}$ treatment reduced the number of IL-17-expressing cells from $0.040 \pm 0.02 \times 10^{6}$ to $0.003 \pm 0.01 \times 10^{6}$ cells and of GM-CSF expressing cells from $0.14 \pm 0.02 \times 10^{6}$ to $0.06 \pm 0.02 \times 10^{6}$ cells in arthritic mice (Figure 7A). In the same experiments, we did not detect significant differences in $\mathrm{CD} 4^{+} \mathrm{IFN} \gamma^{+}, \mathrm{CD} 4^{+} \mathrm{FoxP} 3^{+}$, and $\mathrm{CD}^{+} \mathrm{IL}^{+} 0^{+}$cells (Figure 7A), although a more detailed analysis of the data revealed better regulatory vs. inflammatory balance in GH-treated mice (Figure 7B). In accordance, ELISA data of cytokine production in culture supernatants of anti-CD3 activated cells isolated from these LN showed a GH-mediated significant reduction of IL-17 $(56.33 \pm 19.5 \mathrm{pg} / \mathrm{ml}$ in GH-treated vs. $133.85 \pm 17.5 \mathrm{pg} / \mathrm{ml}$ in controls) and no significant differences in IFN $\gamma(863.58 \pm 157 \mathrm{pg} / \mathrm{ml}$ in GH-treated vs. $974.95 \pm 107 \mathrm{pg} / \mathrm{ml}$
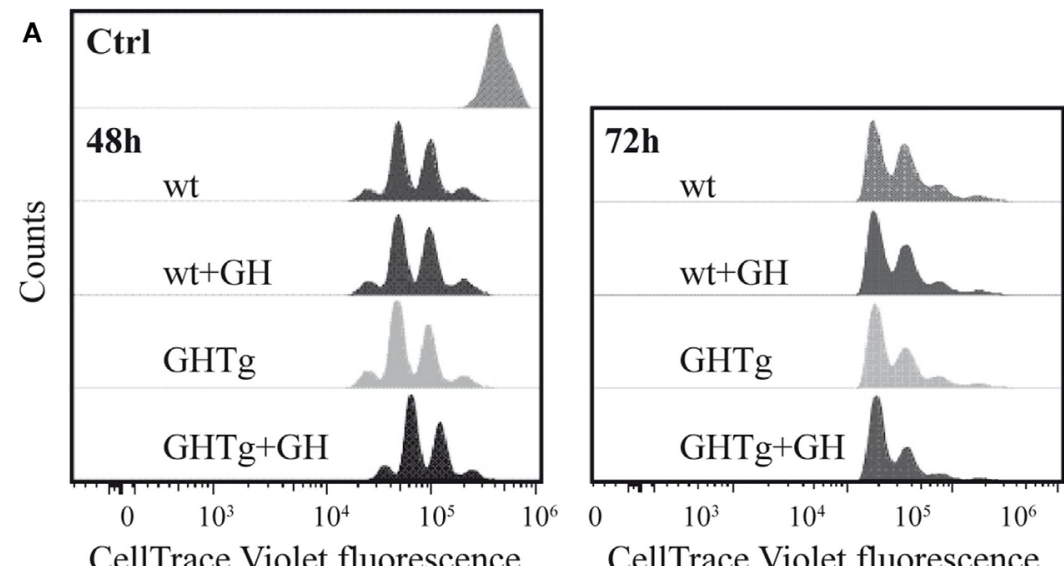

CellTrace Violet fluorescence

CellTrace Violet fluorescence
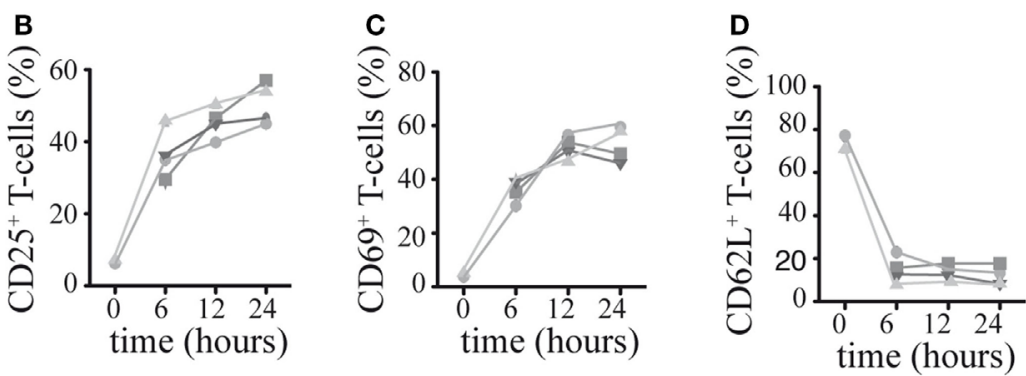

$$
-\mathrm{wt}=\mathrm{wt}+\mathrm{GH} \approx \mathrm{GHTg} \quad \text { GHTg }+\mathrm{GH}
$$

FIGURE 4 | Growth hormone (GH) affects neither bone marrow dendritic cell (BM-DC) antigen presentation nor T cell activation. (A) OT-II mouse CD4+ splenocytes were stained with CellTrace Violet and co-cultured with bone marrow-derived wild-type (wt) or GHTg dendritic cells (BM-DC), alone or with rhGH. Cells were harvested after 48 or $72 \mathrm{~h}$ and analyzed by flow cytometry. A representative experiment is shown of three performed. wt cells at $t=0$ were used as control. CD4+ cells from similar co-cultures were analyzed by flow cytometry at 0, 6, 12, and $24 \mathrm{~h}$ for activation markers CD25 (B), CD69 (C), and CD62L (D). One representative experiment is shown of three performed. 


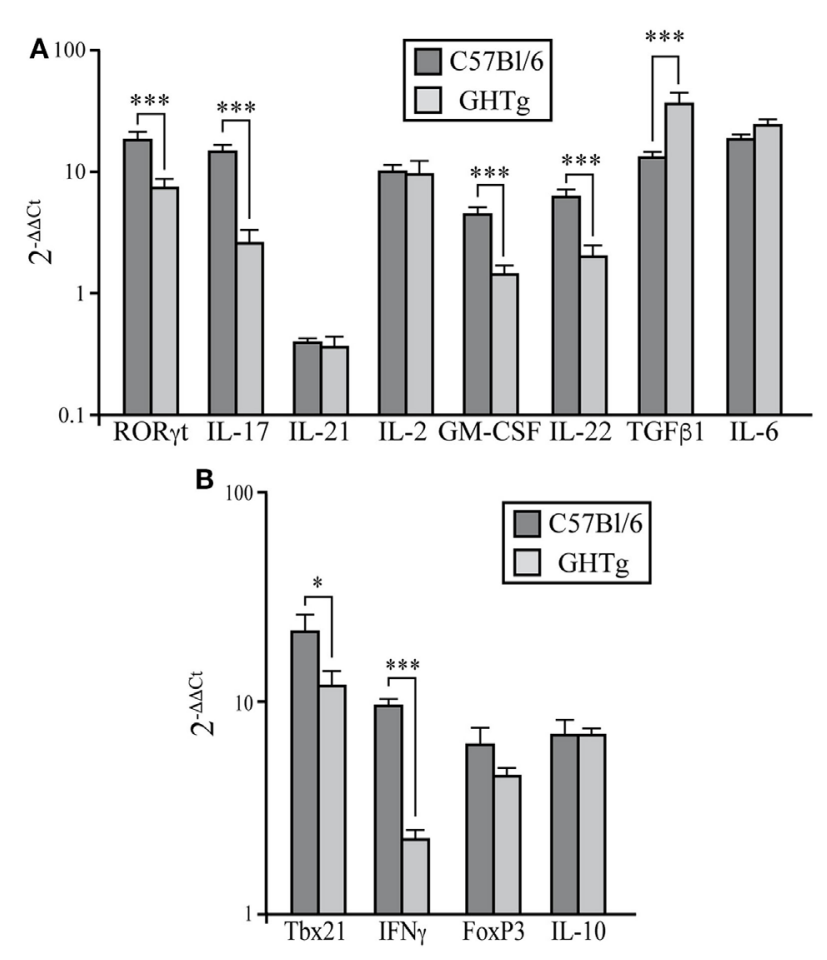

FIGURE 5 | Regulation of pathogenic Th17 profile in collagen-induced arthritis-induced GHTg mice. (A) Expression of characteristic Th17 transcription factors and cytokines in peripheral lymph nodes of collagenimmunized wild-type (wt) and GHTg mice. (B) Expression of transcription factors and cytokines associated to Th1 and Treg cell responses. Cytokine and chemokine mRNA from arthritic mice was quantified by qRT-PCR. Expression is represented as $2^{-\Delta \Delta C t}$ by normalization to $\beta$-actin and the levels of each cytokine in spleen of wt mice; mean \pm SD, Student's $t$-test $(n=12)$; ${ }^{*} p \leq 0.05 ;{ }^{* *} p \leq 0.01 ;{ }^{* *} p \leq 0.001$.

in controls) levels compared to controls (Figure 7C). Together, these data could determine the anti-inflammatory microenvironment triggered by $\mathrm{GH}$, supporting the therapeutic use of $\mathrm{GH}$.

\section{DISCUSSION}

Chronic inflammation underlies many pathologies of clinical importance, including cancer, atherosclerosis, and rheumatic diseases. RA is a systemic autoimmune disease characterized by non-organ-specific autoantibody production and chronic inflammation of synovial tissues, leading to cartilage and bone destruction (29). Current therapies, such as cytokine antagonists, have shown great promise in treating patients (30), although they target the inflammation phase and do not address the initiation or resolution phases, that is, those situations in which the balance between effector and regulatory responses are disrupted (31).

There is evidence that the immune system is greatly influenced by other physiological systems such as the endocrine and neuroendocrine systems (32). GH is produced not only by the pituitary gland but also by lymphoid organs such as the thymus, the spleen, and immune cells in the periphery (33), and the GH receptor is expressed on most leukocyte subpopulations (34). Here, we used
GHTg mice, in which bGH expression is ubiquitous and sustained, to analyze GH effects on induction of experimental arthritis. In a CIA model, we showed that GHTg mice were partially protected compared to wt arthritic littermates. GHTg mice showed delayed disease onset and reduced severity. Pannus, cartilage damage, and bone resorption were detected only in wt CIA mice, whereas we found no sign of joint degradation in GHTg mice at day 30 post-inoculation. It is well known that $\mathrm{GH}$ regulates both bone growth and remodeling, although it is unclear whether they are effects mediated directly or through IGF-I signaling (35). GH modulates both osteoblasts and osteoclasts differentiation and activity (36-38). Although we have not analyzed the activity of osteoblasts in these mice, we did not detect osteoclasts in the joint of collagen-immunized GHTg mice, suggesting that additional causes might also contribute to the resistance to arthritis development in these mice. A previous report described a spontaneous autoimmune-like disorder accompanied by alterations in joints of 6-month-old GHTg mice (39). The phenotype in the joints of these mice includes disorganization of zonal structure, profound alterations in chondrocyte growth/differentiation processes and cartilage damage, and it is complemented by increased levels of auto-anti-DNA antibodies compared to control littermates. The authors, however, rarely found inflammatory infiltrates in synovial tissues indicating that the symptoms detected are more related to osteoarthritis related to bone overgrowth rather than to RA. We did not observe visceromegaly or changes in weight or in length of $\mathrm{DBA} / 1 \mathrm{~J}$ mice treated with exogenous $\mathrm{rhGH}$, but as it is known that GHTg mice develop giantism $(18,40)$, we cannot discard potential side-effects in treatments longer than those used in this study.

In accordance with previous observations $(13,15)$, we detected no major differences in any of the circulating immune cell populations analyzed in basal conditions, although we observed a reduced percentage of $\mathrm{CD}^{+} \mathrm{IFN}^{+}$cells in immunized GHTg mice and a marked increase in the percentage of $\mathrm{B} 220^{+}$cells in LNs of $\mathrm{GHTg}$ mice that was maintained after collagen immunization. We nonetheless noticed a marked reduction in anti-chicken collagen II antibodies in the sera of immunized GHTg mice, although no intrinsic defects were seen in in vitro B cell activation by either anti-IgM antibodies or LPS. We also ruled out defects in the ability of GHTg mouse BM-DC to present antigen and activate T cells in vitro, although the percentage of activated circulating $\mathrm{CD}^{+}$ cells in GHTg mice was lower than in wt arthritic mice.

Autoreactive effector $\mathrm{CD}^{+} \mathrm{T}$ cells, specifically the IFN $\gamma$ producing Th17/Th1 and non-classical Th1 cells, are associated with RA pathogenesis (41). We detected lower IFN $\gamma$ mRNA levels, reduced $\mathrm{CD}^{+} \mathrm{IFN} \gamma^{+}$cells and a significant reduction in Tbx21 expression in LNs from GHTg with respect to wt arthritic mice, which is indicative of the protective role of $\mathrm{GH}$ in CIA. In these mice, ROR $\gamma \mathrm{t}$, IL-17, GM-CSF, and IL-22 mRNA expression was also significantly reduced, indicating a reduction in the percentage of Th17 cells. A similar expression pattern of cytokines was found in GH-treated arthritic DBA/1J mice. Altogether, these results suggest that GH maintains a non-pathogenic profile of Th17 cells. Th17 cell frequency in peripheral blood correlated directly with disease activity. In RA patients, IL-17 levels are similarly increased in synovial fluid (42) and contribute to sustain RA chronicity (24). 

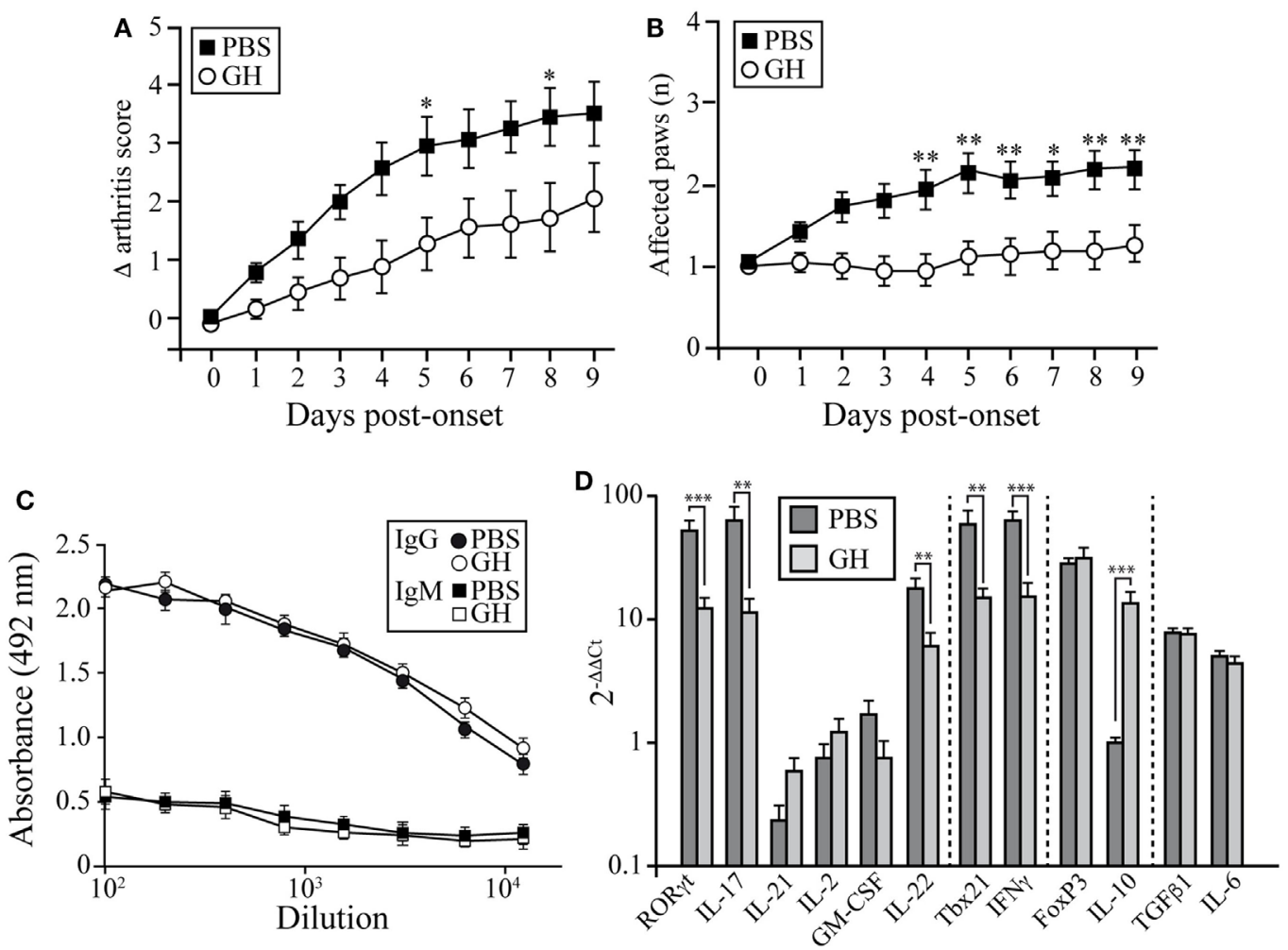

FIGURE 6 | Effect of therapeutic rhGH administration on arthritic mice. Two-month-old DBA/1J mice were immunized with chicken type II collagen. (A) On appearance of the first signs of collagen-induced arthritis (score 2 = treatment day 0 ), affected mice were separated into two groups; one received a daily rhGH injection $(2 \mu \mathrm{g} / \mathrm{ml}, 200 \mu \mathrm{l})$ until day 9, and the other received PBS as control. Clinical scores are expressed as the increase $(\Delta)$ from the initial score at $t=0$ (score 2$)$. Data shown as mean \pm SEM. Student's $t$-test $(n=12) ;{ }^{*} p \leq 0.05$. (B) Mean number of affected paws in arthritic mice as in $(\mathbf{A})$. Data shown as mean \pm SEM. Student's $t$-test $(n=12) ;{ }^{*} p \leq 0.05$. (C) Total anti-collagen type II IgM and IgG were measured in mouse sera by ELISA at the end of the experiment (day 9 post-treatment) of vehicle- (PBS, black line) or rhGH- (gray line) treated arthritic mice as in (A). The figure shows mean absorbance at $492 \mathrm{~nm} \pm \mathrm{SEM}(n=12)$. (D) Expression of characteristic Th17, Th1, and Treg transcription factors and cytokines in peripheral lymph nodes of mice, normalized to $\beta$-actin and expressed as $2^{-\Delta \Delta \mathrm{Ct}}$. Data shown as mean $\pm \mathrm{SD}$. Student's $t$-test ${ }^{\star *} p \leq 0.01 ;{ }^{* \star *} p \leq 0.001$.

There is evidence that Th17 cells are a heterogeneous population composed of several pro- and anti-inflammatory subsets (43). We also observed increased TGF $\beta 1$ and no significant variations in IL-6 mRNA levels. TGF $\beta$ has been associated with the maintenance of peripheral tolerance by inhibiting proliferation and differentiation of autoreactive T cells (44) and promoting survival of Treg cells (45). Although we found no marked differences in the absolute FoxP3 mRNA levels between GHTg and control mice, immunized GHTg mice had a higher FoxP3/ROR $\gamma \mathrm{T}$ ratio, concurring to previous results obtained in a model of diabetes type I in NOD-GHTg mice (15). We also found higher ratio of Treg/Th1 cells after GH treatment of arthritic DBA/1J mice compared to controls. IL- 6 blockade corrects the imbalance between Th17 and Treg cells in patients with RA (46). In the absence of IL-6, TGF $\beta$ do not generate Th17 cells (47-49). Our results thus suggest that GH also favors the immunoregulatory responses.

Development of therapeutic strategies that promote regulatory mechanisms could allow the establishment of robust, sustained resolution of autoimmunity. Moreover, the use of mediators endogenously expressed might reduce the associated sideeffects of these treatments. Here, we demonstrate the beneficial effect of GH administration at the first signs of arthritis in collagen-immunized mice, as well as a clear delay in arthritis progression in GHTg compared to control littermates. Several rheumatic diseases are characterized by abnormalities in the $\mathrm{GH} /$ IGF-1 paracrine axis (50), and although in adults the relationship between serum GH levels and disease progression is debated (51), juvenile chronic arthritis patients have reduced GH levels (52). In the arthritic DBA/1J model, GH treatment did not affect circulating anti-collagen antibody levels, which suggests that in this model, GH modulates the progression and resolution phases of CIA. The mechanism also involved a GH effect on the immune system, as shown by a significant reduction in IFN $\gamma$, IL-17, and IL-22 mRNA levels in LNs of GH-treated CIA mice, with a concomitant increase of IL-10. In contrast of these results, IL-10 expression was not elevated in GHTg mice. Although more experiments are needed to clarify this discrepancy, differences in circulating levels of GH between GHTg and GH-treated DBA/1J mice might cause this difference. Whereas GHTg mice have sustained GH levels in sera $(\sim 5 \mu \mathrm{g} / \mathrm{ml})$, wt mice have a pulsatile and circadian expression of $\mathrm{GH}$ that in our DBA/1J model is modified by the exogenous administration of the hormone $(2 \mu \mathrm{g} / \mathrm{ml})$. Acute responses of GH must thus differ in both mouse models as well as how mice are adapted to this circumstance. 

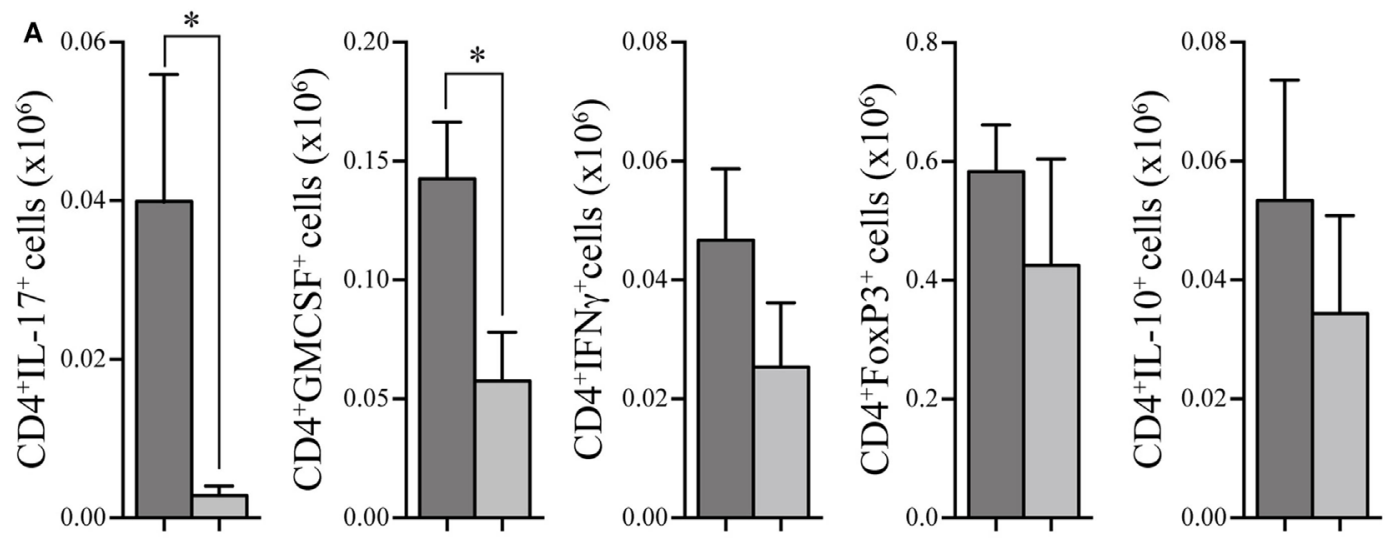

\section{$\square$ CIA $\square$ CIA $+\mathrm{GH}$}
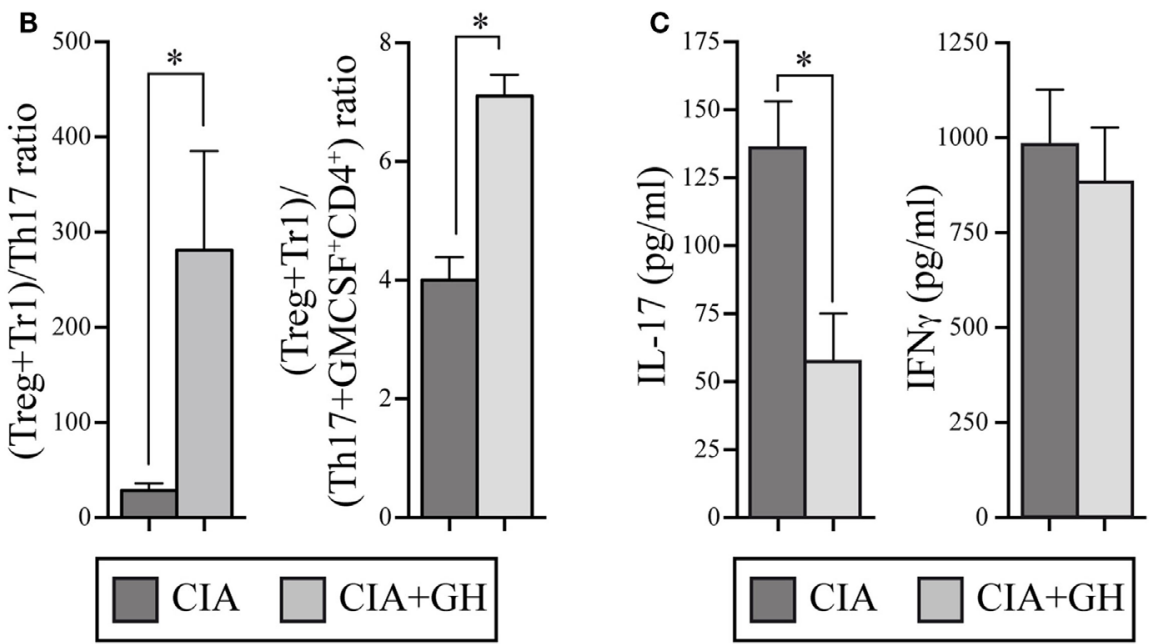

FIGURE 7 | rhGH treatment of arthritic DBA/1 J mice modulates the inflammatory cytokine profile in lymph nodes (LNs). (A) Quantitation of total number of cytokine-producing CD4+ T cells (IL-17, GM-CSF, IFN $\gamma$, and IL-10) and regulatory CD4+ T cells (FoxP3 ${ }^{+}$) from a mixture of popliteal and inguinal LN cells. Data are the mean \pm SEM of two different experiments [controls $n=10$; growth hormone $(\mathrm{GH})$-treated $n=11$ ]. Mann-Whitney $U$-test ${ }^{*} p \leq 0.05$. (B) Ratios of $($ Tregs + Tr1)/

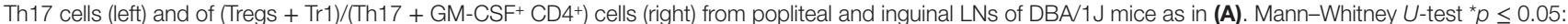
Tregs (CD4 ${ }^{+}$FoxP3 ${ }^{+}$cells); Tr1 (CD4+ IL-10+ cells); Th17 (CD4+IL-17 ${ }^{+}$cells). (C) Levels of IL-17 and IFN $\gamma$ in culture supernatants of cells isolated from LNs in (A) and activated in vitro $(48 \mathrm{~h})$ with anti-CD3 $\mathrm{mAb}$. Data shown as mean $\pm \mathrm{SD}$. Student's $t$-test ${ }^{*} p \leq 0.05$.

Our flow cytometry data on peripheral LNs cells from arthritic DBA/1J mice confirmed the effect of GH treatment on the reduction number of Th17 and $\mathrm{CD} 4{ }^{+} \mathrm{GM}-\mathrm{CSF}^{+} \mathrm{T}$ cells. These data correlated with the significant reduction of CCL20 levels found in LNs of mice treated with the hormone. CCL20 binds to CCR6, an important chemokine receptor for Th17 cells movement (28). CCR6 expression by Th17 cells allows their migration across the endothelial barrier in several autoimmune diseases such as multiple sclerosis (53) or RA (54). The analysis, however, did not show modifications in the number of $\mathrm{CD}^{+}{ }^{+} \mathrm{Foxp}^{+}$and $\mathrm{CD} 4^{+} \mathrm{IL}-10^{+} \mathrm{T}$ cells, discarding the participation of these cells in the increase of IL-10 levels found in GH-treated mice. Mesenchymal stem cells (MSCs) are capable of suppressing the immune response by inhibiting the maturation of dendritic cells and suppressing the function of T lymphocytes, B lymphocytes, and natural killer cells in autoimmune and inflammatory diseases
(55). In in vitro experiments, MSCs prevent the differentiation of naïve $\mathrm{CD}^{+} \mathrm{T}$ cells into Th17 cells and inhibited the production of IL-17, IL-22, IFN- $\gamma$, and TNF- $\alpha$ by fully differentiated Th17 cells, inducing the expression of Foxp3 and IL-10 production (56). We observed higher ratio of (Treg + Tr1)/Th17 and of (Treg + Tr1)/

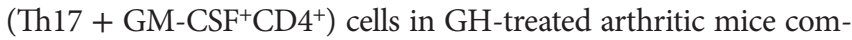
pared to controls. Taking into account that MSC express a functional GH receptor (57), we can hypothesize that via mobilization from their reservoirs and/or by affecting their tropism, GH treatment might facilitate the presence of MSC in the LNs, thus favoring IL-10mediated regulatory responses. By increasing in the LNs the levels of Tregs cells, including CD4 ${ }^{+}$IL $10^{+}$Tr1 cells, and triggering Th17 cell plasticity toward an IL10-driven anti-inflammatory response, adipose-derived MSCs ameliorated established CIA (58). The combination between MSC and IL-10-producing $\operatorname{Tr} 1$ cells prevents 
the development of destructive arthritis (59). Although we did not observe significant differences in the percentage of $\mathrm{F} 4 / 80^{+} \mathrm{IL}-10^{+}$ cells between GH-treated DBA/1J and control mice, MSCs can also modulate macrophage differentiation toward an anti-inflammatory phenotype $(60,61)$. MSC also induce regulatory DCs in the LNs (62). This subpopulation of DCs are characterized by the secretion of high levels of IL-10 which is essential for the regulation of the immune responses (63). To clarify all these hypotheses, new experiments are actually in progress.

The reduction of Tbx 21 levels detected in $\mathrm{GH}$-treated mice also suggest that exogenous $\mathrm{GH}$ repolarizes Th17 cells to a less aggressive phenotype and/or blocks the acquisition of a pathogenic profile of this Th17 cells. GH triggers JAK2/STAT5 phosphorylation (64) and STAT5 controls not only Th2 but also Th1 and Th17 differentiation; IL- 2 regulates Th1 and Th17 differentiation, which induces STAT5-dependent IL-12R $\beta 2$ and Tbx21 in Th1 cells and IL-17 expression by Th17 cells (65). We can thus hypothesize that $\mathrm{GH}$ treatment regulates the expression of genes involved in T cell polarization by altering STAT5 phosphorylation directly or indirectly via SOCS expression regulation.

Our results confirm the importance of $\mathrm{GH}$ in regulating immune system plasticity, and thus its value as a regulatory mechanism that limits the effector response and maintains immune system homeostasis. Recombinant human GH improves survival and protects against acute lung injury in murine Staphylococcus aureus sepsis (66) and protects from acute pancreatitis (67). GH decreases gut inflammation and improves or maintains gut barrier function, which ultimately inhibits development of inflammatory bowel disease $(14,68)$; co-administration of epidermal growth factor and GH-releasing peptide-6, a GH secretagogue, improves clinical recovery in experimental autoimmune encephalitis (69). $\mathrm{GH}$ is thus a candidate for potential treatment of inflammatory disorders and therapy for arthritis and other autoimmune diseases.

\section{REFERENCES}

1. Olney RC. Regulation of bone mass by growth hormone. Med Pediatr Oncol (2003) 41:228-34. doi:10.1002/mpo.10342

2. Velloso CP. Regulation of muscle mass by growth hormone and IGF-I. Br J Pharmacol (2008) 154:557-68. doi:10.1038/bjp.2008.153

3. Vijayakumar A, Novosyadlyy R, Wu Y, Yakar S, LeRoith D. Biological effects of growth hormone on carbohydrate and lipid metabolism. Growth Horm IGF Res (2010) 20:1-7. doi:10.1016/j.ghir.2009.09.002

4. Veldhuis JD, Roemmich JN, Rogol AD. Gender and sexual maturationdependent contrasts in the neuroregulation of growth hormone secretion in prepubertal and late adolescent males and females - a general clinical research center-based study. J Clin Endocrinol Metab (2000) 85:2385-94. doi:10.1210/ jc.85.7.2385

5. Takano A, Haruta T, Iwata M, Usui I, Uno T, Kawahara J, et al. Growth hormone induces cellular insulin resistance by uncoupling phosphatidylinositol 3-kinase and its downstream signals in 3T3-L1 adipocytes. Diabetes (2001) 50:1891-900. doi:10.2337/diabetes.50.8.1891

6. Hattori N, Saito T, Yagyu T, Jiang BH, Kitagawa K, Inagaki C. GH, GH receptor, GH secretagogue receptor, and ghrelin expression in human T cells, B cells, and neutrophils. J Clin Endocrinol Metab (2001) 86:4284-91. doi:10.1210/ jcem.86.9.7866

7. Welniak LA, Sun R, Murphy WJ. The role of growth hormone in T-cell development and reconstitution. J Leukoc Biol (2002) 71:381-7. doi:10.1189/jlb.71.3.381

8. Murphy WJ, Durum SK, Longo DL. Human growth hormone promotes engraftment of murine or human $\mathrm{T}$ cells in severe combined immunodeficient

\section{ETHICS STATEMENT}

Mice were handled according to national and European Union guidelines, and experiments were approved by the Comité Ético de Experimentación Animal, Centro Nacional de Biotecnología and the Regional Government (PROEX 250-16).

\section{AUTHOR CONTRIBUTIONS}

RV, GC, YJ, ML-S, EG-C, JR-F, JL, and PL performed the experiments and analyzed the data. GC, CM-A, MG, and RPG designed experiments and interpreted the data. RV, GC, YJ, JLP, CM-A, MG, and RPG revised critically the manuscript. RV and MM conceived the idea designed the experiments, interpreted data, and wrote the manuscript. All the authors have revised and approved the final version of the manuscript.

\section{FUNDING}

This work was supported in part by grants from the Spanish Ministry of Economy and Competitiveness (SAF 2014-53416R; SAF 2017-82940-R AEI/FEDER, EU), from the RETICS Program of the Instituto de Salud Carlos III (RD12/0009/0009, RD12/0009/0002, RD16/0012/0006, and RD16/0012/0008; RIER and PI17/01161), from the Regional Government of Madrid (B2017/BMD-3804), and the Ramón Areces Foundation. We are grateful for the gift of Genotonorm (Pfizer Spain). We thank I. Jareño for animal handling and C. Mark for editorial assistance.

\section{SUPPLEMENTARY MATERIAL}

The Supplementary Material for this article can be found online at https://www.frontiersin.org/articles/10.3389/fimmu.2018.01165/ full\#supplementary-material.

mice. Proc Natl Acad Sci U S A (1992) 89:4481-5. doi:10.1073/pnas.89. 10.4481

9. Kimata H, Fujimoto M. Growth hormone and insulin-like growth factor I induce immunoglobulin (Ig)E and IgG4 production by human B cells. J Exp Med (1994) 180:727-32. doi:10.1084/jem.180.2.727

10. Kimata H, Yoshida A. Differential effect of growth hormone and insulin-like growth factor-I, insulin-like growth factor-II, and insulin on Ig production and growth in human plasma cells. Blood (1994) 83:1569-74.

11. Bidlingmaier M, Auernhammer CJ, Feldmeier H, Strasburger CJ. Effects of growth hormone and insulin-like growth factor I binding to natural killer cells. Acta Paediatr Suppl (1997) 423:80-1. doi:10.1111/j.1651-2227.1997. tb18378.x

12. Lu C, Kumar PA, Fan Y, Sperling MA, Menon RK. A novel effect of growth hormone on macrophage modulates macrophage-dependent adipocyte differentiation. Endocrinology (2010) 151:2189-99. doi:10.1210/en.2009-1194

13. Gonzalo JA, Mazuchelli R, Mellado M, Frade JM, Carrera AC, von Kobbe C, et al. Enterotoxin septic shock protection and deficient $\mathrm{T}$ helper 2 cytokine production in growth hormone transgenic mice. JImmunol (1996) 157: 3298-304.

14. Han X, Benight N, Osuntokun B, Loesch K, Frank SJ, Denson LA. Tumour necrosis factor alpha blockade induces an anti-inflammatory growth hormone signalling pathway in experimental colitis. Gut (2007) 56:73-81. doi:10.1136/ gut.2006.094490

15. Villares R, Kakabadse D, Juarranz Y, Gomariz RP, Martinez AC, Mellado M. Growth hormone prevents the development of autoimmune diabetes. Proc Natl Acad Sci U S A (2013) 110:E4619-27. doi:10.1073/pnas.1314985110 
16. McInnes IB, Schett G. The pathogenesis of rheumatoid arthritis. N Engl J Med (2011) 365:2205-19. doi:10.1056/NEJMra1004965

17. Catrina AI, Svensson CI, Malmstrom V, Schett G, Klareskog L. Mechanisms leading from systemic autoimmunity to joint-specific disease in rheumatoid arthritis. Nat Rev Rheumatol (2017) 13:79-86. doi:10.1038/nrrheum. 2016.200

18. McGrane MM, Yun JS, Roesler WJ, Park EA, Wagner TE, Hanson RW. Developmental regulation and tissue-specific expression of a chimaeric phosphoenolpyruvate carboxykinase/bovine growth hormone gene in transgenic animals. J Reprod Fertil Suppl (1990) 41:17-23.

19. Inglis JJ, Criado G, Medghalchi M, Andrews M, Sandison A, Feldmann M, et al. Collagen-induced arthritis in C57BL/6 mice is associated with a robust and sustained T-cell response to type II collagen. Arthritis Res Ther (2007) 9:R113. doi:10.1186/ar2319

20. Inaba K, Swiggard WJ, Steinman RM, Romani N, Schuler G, Brinster C. Isolation of dendritic cells. Curr Protoc Immunol (2009) Chapter 3:Unit 3.7. doi:10.1002/0471142735.im0307s86

21. Cascio G, Martin-Cofreces NB, Rodriguez-Frade JM, Lopez-Cotarelo P, Criado G, Pablos JL, et al. CXCL12 regulates through JAK1 and JAK2 formation of productive immunological synapses. J Immunol (2015) 194:5509-19. doi:10.4049/jimmunol.1402419

22. Maldonado RA, Irvine DJ, Schreiber R, Glimcher LH. A role for the immunological synapse in lineage commitment of CD4 lymphocytes. Nature (2004) 431:527-32. doi:10.1038/nature02916

23. Brand DD, Latham KA, Rosloniec EF. Collagen-induced arthritis. Nat Protoc (2007) 2:1269-75. doi:10.1038/nprot.2007.173

24. Benedetti G, Miossec P. Interleukin 17 contributes to the chronicity of inflammatory diseases such as rheumatoid arthritis. Eur J Immunol (2014) 44:339-47. doi:10.1002/eji.201344184

25. Mellado M, Martinez-Munoz L, Cascio G, Lucas P, Pablos JL, RodriguezFrade JM. T cell migration in rheumatoid arthritis. Front Immunol (2015) 6:384. doi:10.3389/fimmu.2015.00384

26. Shahrara S, Huang Q, Mandelin AM II, Pope RM. TH-17 cells in rheumatoid arthritis. Arthritis Res Ther (2008) 10:R93. doi:10.1186/ar2477

27. Park MJ, Park HS, Oh HJ, Lim JY, Yoon BY, Kim HY, et al. IL-17-deficient allogeneic bone marrow transplantation prevents the induction of collageninduced arthritis in DBA/1J mice. Exp Mol Med (2012) 44:694-705. doi:10.3858/emm.2012.44.11.078

28. Singh SP, Zhang HH, Foley JF, Hedrick MN, Farber JM. Human T cells that are able to produce IL-17 express the chemokine receptor CCR6. J Immunol (2008) 180:214-21. doi:10.4049/jimmunol.180.1.214

29. Smolen JS, Aletaha D, McInnes IB. Rheumatoid arthritis. Lancet (2016) 388:2023-38. doi:10.1016/S0140-6736(16)30173-8

30. McInnes IB, Schett G. Pathogenetic insights from the treatment of rheumatoid arthritis. Lancet (2017) 389:2328-37. doi:10.1016/S0140-6736(17)31472-1

31. Rosenblum MD, Remedios KA, Abbas AK. Mechanisms of human autoimmunity. J Clin Invest (2015) 125:2228-33. doi:10.1172/JCI78088

32. Tang MW, Garcia S, Gerlag DM, Tak PP, Reedquist KA. Insight into the endocrine system and the immune system: a review of the inflammatory role of prolactin in rheumatoid arthritis and psoriatic arthritis. Front Immunol (2017) 8:720. doi:10.3389/fimmu.2017.00720

33. Savino W, Postel-Vinay MC, Smaniotto S, Dardenne M. The thymus gland: a target organ for growth hormone. Scand J Immunol (2002) 55:442-52. doi:10.1046/j.1365-3083.2002.01077.x

34. Meazza C, Pagani S, Travaglino P, Bozzola M. Effect of growth hormone (GH) on the immune system. Pediatr Endocrinol Rev (2004) 1(Suppl 3):490-5.

35. Isaksson OG, Jansson JO, Gause IA. Growth hormone stimulates longitudinal bone growth directly. Science (1982) 216:1237-9. doi:10.1126/science.7079756

36. Ernst M, Rodan GA. Increased activity of insulin-like growth factor (IGF) in osteoblastic cells in the presence of growth hormone (GH): positive correlation with the presence of the GH-induced IGF-binding protein BP-3. Endocrinology (1990) 127:807-14. doi:10.1210/endo-127-2-807

37. Kassem M, Mosekilde L, Eriksen EF. Growth hormone stimulates proliferation of normal human bone marrow stromal osteoblast precursor cells in vitro. Growth Regul (1994) 4:131-5.

38. Nishiyama K, Sugimoto T, Kaji H, Kanatani M, Kobayashi T, Chihara K. Stimulatory effect of growth hormone on bone resorption and osteoclast differentiation. Endocrinology (1996) 137:35-41. doi:10.1210/endo.137.1. 8536635
39. Ogueta S, Olazabal I, Santos I, Delgado-Baeza E, Garcia-Ruiz JP. Transgenic mice expressing bovine GH develop arthritic disorder and self-antibodies. J Endocrinol (2000) 165:321-8. doi:10.1677/joe.0.1650321

40. Frohman LA. New insights into the regulation of somatotrope function using genetic and transgenic models. Metabolism (1996) 45:1-3. doi:10.1016/ S0026-0495(96)90067-0

41. Kotake S, Yago T, Kobashigawa T, Nanke Y. The plasticity of Th17 cells in the pathogenesis of rheumatoid arthritis. J Clin Med (2017) 6:263-72. doi:10.3390/ jcm6070067

42. Leipe J, Grunke M, Dechant C, Reindl C, Kerzendorf U, Schulze-Koops H, et al. Role of Th17 cells in human autoimmune arthritis. Arthritis Rheum (2010) 62:2876-85. doi:10.1002/art.27622

43. Sundrud MS, Trivigno C. Identity crisis of Th17 cells: many forms, many functions, many questions. Semin Immunol (2013) 25:263-72. doi:10.1016/j. smim.2013.10.021

44. Li MO, Flavell RA. TGF-beta: a master of all T cell trades. Cell (2008) 134:392-404. doi:10.1016/j.cell.2008.07.025

45. Li MO, Sanjabi S, Flavell RA. Transforming growth factor-beta controls development, homeostasis, and tolerance of $\mathrm{T}$ cells by regulatory $\mathrm{T}$ celldependent and -independent mechanisms. Immunity (2006) 25:455-71. doi:10.1016/j.immuni.2006.07.011

46. Samson M, Audia S, Janikashvili N, Ciudad M, Trad M, Fraszczak J, et al. Brief report: inhibition of interleukin-6 function corrects Th17/Treg cell imbalance in patients with rheumatoid arthritis. Arthritis Rheum (2012) 64:2499-503. doi:10.1002/art.34477

47. Korn T, Bettelli E, Gao W, Awasthi A, Jager A, Strom TB, et al. IL-21 initiates an alternative pathway to induce proinflammatory $\mathrm{T}(\mathrm{H}) 17$ cells. Nature (2007) 448:484-7. doi:10.1038/nature05970

48. Nurieva R, Yang XO, Martinez G, Zhang Y, Panopoulos AD, Ma L, et al. Essential autocrine regulation by IL-21 in the generation of inflammatory T cells. Nature (2007) 448:480-3. doi:10.1038/nature05969

49. Zhou L, Ivanov II, Spolski R, Min R, Shenderov K, Egawa T, et al. IL-6 programs $\mathrm{T}(\mathrm{H})-17$ cell differentiation by promoting sequential engagement of the IL-21 and IL-23 pathways. Nat Immunol (2007) 8:967-74. doi:10.1038/ni1488

50. Denko CW, Malemud CJ. Role of the growth hormone/insulin-like growth factor-1 paracrine axis in rheumatic diseases. Semin Arthritis Rheum (2005) 35:24-34. doi:10.1016/j.semarthrit.2005.03.001

51. Malemud CJ. Growth hormone, VEGF and FGF: involvement in rheumatoid arthritis. Clin Chim Acta (2007) 375:10-9. doi:10.1016/j.cca.2006.06.033

52. Allen RC, Jimenez M, Cowell CT. Insulin-like growth factor and growth hormone secretion in juvenile chronic arthritis. Ann Rheum Dis (1991) 50:602-6. doi:10.1136/ard.50.9.602

53. Restorick SM, Durant L, Kalra S, Hassan-Smith G, Rathbone E, Douglas MR, et al. CCR6(+) Th cells in the cerebrospinal fluid of persons with multiple sclerosis are dominated by pathogenic non-classic Th1 cells and GM-CSFonly-secreting Th cells. Brain Behav Immun (2017) 64:71-9. doi:10.1016/j. bbi.2017.03.008

54. Hirota K, Yoshitomi H, Hashimoto M, Maeda S, Teradaira S, Sugimoto N, et al. Preferential recruitment of CCR6-expressing Th17 cells to inflamed joints via CCL20 in rheumatoid arthritis and its animal model. J Exp Med (2007) 204:2803-12. doi:10.1084/jem.20071397

55. Gao F, Chiu SM, Motan DA, Zhang Z, Chen L, Ji HL, et al. Mesenchymal stem cells and immunomodulation: current status and future prospects. Cell Death Dis (2016) 7:e2062. doi:10.1038/cddis.2015.327

56. Ghannam S, Bouffi C, Djouad F, Jorgensen C, Noel D. Immunosuppression by mesenchymal stem cells: mechanisms and clinical applications. Stem Cell Res Ther (2010) 1:2. doi:10.1186/scrt2

57. Wang JR, Ahmed SF, Gadegaard N, Meek RM, Dalby MJ, Yarwood SJ. Nanotopology potentiates growth hormone signalling and osteogenesis of mesenchymal stem cells. Growth Horm IGF Res (2014) 24:245-50. doi:10.1016/j.ghir.2014.10.003

58. Lopez-Santalla M, Mancheno-Corvo P, Menta R, Lopez-Belmonte J, DelaRosa O, Bueren JA, et al. Human adipose-derived mesenchymal stem cells modulate experimental autoimmune arthritis by modifying early adaptive $\mathrm{T}$ cell responses. Stem Cells (2015) 33:3493-503. doi:10.1002/stem.2113

59. Lim JY, Im KI, Lee ES, Kim N, Nam YS, Jeon YW, et al. Enhanced immunoregulation of mesenchymal stem cells by IL-10-producing type 1 regulatory T cells in collagen-induced arthritis. Sci Rep (2016) 6:26851. doi:10.1038/ srep26851 
60. Cho DI, Kim MR, Jeong HY, Jeong HC, Jeong $\mathrm{MH}$, Yoon $\mathrm{SH}$, et al. Mesenchymal stem cells reciprocally regulate the M1/M2 balance in mouse bone marrow-derived macrophages. Exp Mol Med (2014) 46:e70. doi:10.1038/ emm.2013.135

61. Lopez-Santalla M, Menta R, Mancheno-Corvo P, Lopez-Belmonte J, DelaRosa O, Bueren JA, et al. Adipose-derived mesenchymal stromal cells modulate experimental autoimmune arthritis by inducing an early regulatory innate cell signature. Immun Inflamm Dis (2016) 4:213-24. doi:10.1002/iid3.106

62. Zhao ZG, Xu W, Sun L, You Y, Li F, Li QB, et al. Immunomodulatory function of regulatory dendritic cells induced by mesenchymal stem cells. Immunol Invest (2012) 41:183-98. doi:10.3109/08820139.2011.607877

63. Zhang M, Tang H, Guo Z, An H, Zhu X, Song W, et al. Splenic stroma drives mature dendritic cells to differentiate into regulatory dendritic cells. Nat Immunol (2004) 5:1124-33. doi:10.1038/ni1130

64. Wang X, Darus CJ, Xu BC, Kopchick JJ. Identification of growth hormone receptor (GHR) tyrosine residues required for GHR phosphorylation and JAK2 and STAT5 activation. Mol Endocrinol (1996) 10:1249-60. doi:10.1210/ me.10.10.1249

65. Liao W, Lin JX, Wang L, Li P, Leonard WJ. Modulation of cytokine receptors by IL-2 broadly regulates differentiation into helper T cell lineages. Nat Immunol (2011) 12:551-9. doi:10.1038/ni.2030

66. Yi C, Cao Y, Mao SH, Liu H, Ji LL, Xu SY, et al. Recombinant human growth hormone improves survival and protects against acute lung injury in murine Staphylococcus aureus sepsis. Inflamm Res (2009) 58:855-62. doi:10.1007/ s00011-009-0056-0
67. Jaworek J, Leja-Szpak A, Dembinski A, Tomaszewska R, Szklarczyk J, Kot M, et al. Involvement of sensory nerves in the protective effect of growth hormone on acute pancreatitis. Growth Horm IGF Res (2009) 19:517-22. doi:10.1016/ j.ghir.2009.06.001

68. Soendergaard C, Kvist PH, Thygesen P, Reslow M, Nielsen OH, Kopchick JJ, et al. Characterization of growth hormone resistance in experimental and ulcerative colitis. Int J Mol Sci (2017) 18:1-20. doi:10.3390/ijms18102046

69. del Barco DG, Montero E, Coro-Antich RM, Brown E, Suarez-Alba J, Lopez L, et al. Coadministration of epidermal growth factor and growth hormone releasing peptide-6 improves clinical recovery in experimental autoimmune encephalitis. Restor Neurol Neurosci (2011) 29:243-52. doi:10.3233/ RNN-2011-0595

Conflict of Interest Statement: The authors declare that the research was conducted in the absence of any commercial or financial relationships that could be construed as a potential conflict of interest.

Copyright (c) 2018 Villares, Criado, Juarranz, Lopez-Santalla, García-Cuesta, Rodríguez-Frade, Leceta, Lucas, Pablos, Martínez-A, Garin, Gomariz and Mellado. This is an open-access article distributed under the terms of the Creative Commons Attribution License (CC BY). The use, distribution or reproduction in other forums is permitted, provided the original author(s) and the copyright owner are credited and that the original publication in this journal is cited, in accordance with accepted academic practice. No use, distribution or reproduction is permitted which does not comply with these terms. 